\title{
Possible Horizons For EducATIONAL INNOVATION IN COLOMBIA THROUGH CONTEMPORARY TECHNOLOGICAL Perspectives: A Training Experience With tic. Contributions of The Project ANAlysis MOdel Redco CIER OCCIDENTE
}

\author{
Eugenia Ramírez-Isaza ${ }^{1}$
}

1 Ph.D. in Didactic in New Technologies. Teaching Researcher, Knowledge Network REDCo and Research Line Education and Virtuality, GITT Group Coordinator. Universidad de Antioquia, Medellín, Colombia.

E-mail:eramirezisaza@gmail.com

Received date: August 13, 2016 Accepted date: November 15, 2016

How to cite this article: E. Ramírez-Isaza, "Possible Horizons for Educational Innovation in Colombia through Contemporary Technological Perspectives. A Training Experience with TIC. Contributions of the Project Analysis Model REDCO CIER Occidente", Ingeniería Solidaria, vol. 13, n. ${ }^{\circ}$ 21, pp. 63-70, January 2017. doi: http://dx.doi.org/10.16925/in.v13i21.1730

\begin{abstract}
Introduction: This paper presents an overview of the lecture presented to UNESCO-UNIR TIC \& Education Latam Congress 2016, conducted by UNESCO and coordinated by Universidad de la Rioja, (UNIR) in Spain. The lecture was named "Contributions of the Analysis Model as a systematization of project research REDCo Knowledge Network: CIER Occidente" enlightened about the systematization of the final report of the research work that the Education and Virtuality Research Line of the GITT Group (in Terminology and Translation) of Universidad de Antioquia performed between 2014 and 2015 as one of the five universities that participated in the Project of Colciencias CIER Occidente, through its Macro Project: REDCo Knowledge Network. Methodology: This paper begins with an ample view of REDCO as knowledge network to characterize the core of the research project in question, where REDCO was endorsed as a pedagogical methodological matrix based on the appropriation of ICT in two EI (Innovative schools) as a basic scenario where multiple paths, channels, and languages coincide, this by a strong technological component. Results and Conclusions: REDCO CIER Occidente promotes teacher training, considering that the chain value in education is teacher centered, as teachers are who program the learning activities, who need to improve the processes, who use new media and share knowledge and good practices to improve the academic services and refine the outcomes.
\end{abstract}

Keywords: knowledge network, model of analysis, qualitative research, methodological component, teacher training, virtual learning scenarios. 


\section{Horizontes POSIBLES PARA LA INNOVACIÓN EDUCATIVA EN COLOMBia A TRAVÉS DE PERSPECTIVAS TECNOLÓGICAS CONTEMPORÁNEAS: UNA EXPERIENCIA DE FORMACIÓN CON TIC. CONTRIBUCIONES DEL MODELO DE ANÁlisis de PROYECTOS REDCO CIER OCCIDENTE}

Resumen. Introducción: este artículo presenta una visión de conjunto sobre la conferencia presentada en UNESCO-UNIR TIC \& Education Latam Congress 2016, realizada por la UNESCO y coordinada por la Universidad de la Rioja (UNIR) en España. La conferencia se tituló "Aportaciones del modelo de análisis como sistematización del proyecto de investigación REDCo Knowledge Network: CIER Occidente" y trató sobre la sistematización del informe final del trabajo de investigación que la línea de investigación en Educación y virtualidad del Grupo GITT (en terminología y traducción) de la Universidad de Antioquia realizó entre 2014 y 2015, siendo esta una de las cinco universidades que participaron en el proyecto de Colciencias CIER Occidente, a través de su macro proyecto REDCo Knowledge Network. Metodología: este trabajo parte de una visión amplia de REDCO como red de conocimiento para caracterizar el núcleo del proyecto de investigación en cuestión, en el que REDCo fue aprobado como una matriz pedagógica y metodológica basada en la apropiación de las TIC en dos EI (Escuelas Innovadoras) como escenario básico en el que múltiples caminos, canales y lenguajes coinciden, gracias a un fuerte componente tecnológico. Resultados y Conclusiones: REDCO CIER Occidente promueve la formación docente, considerando que el valor de la cadena educativa está centrado en el docente, ya que es este el que programa las actividades de aprendizaje, necesita mejorar los procesos, y también, el que utiliza los nuevos medios, comparte conocimientos y buenas prácticas para mejorar los servicios académicos y refinar los resultados.

Palabras clave: red de conocimiento, modelo de análisis, investigación cualitativa, componente metodológico, formación de profesores, escenarios virtuales de aprendizaje.

\section{Horizontes possíveis PARA A INOVAÇão EDUCATIVA NA COLÔMbia POR MEIO de PERSPECTIVAS TECNOLÓGICAS CONTEMPORÂNEAS: UMA EXPERIÊNCIA DE FORMAÇÃO COM TIC. CONTRIBUIÇÕES DO MODELO DE ANÁlise de PROJETOS REDCO CIER OCIDENTE}

Resumo. Introdução: este artigo apresenta uma visão de conjunto sobre a conferência apresentada na UNESCO-UNIR TIC \& Education Latam Congress 2016, realizada pela Unesco e coordenada pela Universidad de la Rioja (UNIR) na Espanha. A conferência foi intitulada "Contribuições do modelo de análise como sistematização do projeto de pesquisa redco Knowledge Network: cIER Occidente" e tratou sobre a sistematização do relatório final do trabalho de pesquisa que a linha de pesquisa em educação e virtualidade do Grupo GITT (em terminologia e tradução) da Universidad de Antioquia realizou entre 2014 e 2015, sendo esta uma das cinco universidades que participaram do projeto do Colciencias CIER Occidente, por meio de seu macroprojeto redco Knowledge Network. Metodologia: este trabalho parte de uma visão ampla de redco como rede de conhecimento para caracterizar o núcleo do projeto de pesquisa em questão, no qual redco foi aprovado como uma matriz pedagógica e metodológica baseada na apropriação das tic em duas Escolas Inovadoras (EI) como cenário básico no qual múltiplos caminhos, canais e linguagens coincidem graças a um forte componente tecnológico. Resultados e conclusões: redco cier Occidente promove a formação docente, considerando que o valor da rede educativa está focado no docente, já que é o que programa as atividades de aprendizagem, necessita melhorar os processos e também o que utiliza os novos meios, compartilha conhecimentos e boas práticas para melhorar os serviços acadêmicos e refinar os resultados.

Palavras-chave: rede de conhecimento, modelo de análise, pesquisa qualitativa, componente metodológico, formação de professores, cenários virtuais de aprendizagem. 


\section{Introduction}

This work pretends to ech the latest contributions given at the Conferences and World Summits of Higher Education carried out by international organizations, including unESCO. In these, an urgent and emphatic call is made to members of educational communities - particularly those in charge of public and strategic policies, to those responsible for the Ministries of Education, Higher Education Institutions, of Culture and Science and Technology, international organizations, UNESCO itself, and the actors and people involved in educational and university tasks - to consider the approaches and lines of action that derived from the debate about the priorities that Higher Education must take. Such priorities must take in account that this is for the development of the Ibero-American region. It is in this context that we intend to anchor the results of the REDCo CIER Occidente Project towards a perspective that demarcates possible horizons as a result of the research carried out in the Colombian educational context on the advances given by the new ways of constructing, managing and transferring knowledge, and where TIC as a national policy has a framework for development in the local and regional education sector.

In these events, it is pointed out that, although progress has been made towards a society that seeks democratic changes and sustainable referents, there is still a lack of thoughtful changes in the axes that will stimulate the development of the region, among which one of the most important aspects is education and preeminently Higher Education. On the other hand, research in the Ibero-American educational sector confirms the historical moment in the policy of integration and insertion of Information and Communications Technology (ICT) as a substratum at international level. The importance of this communication phenomenon towards development within globalization is undeniable. Such research shows how ICT, as technological tools, have advantaged the social processes of exchange and interaction, not only in the provision of services, but also in the opening borders of the political, economic and cultural spheres.

However, it is determined, according to up-todate diagnoses, that in the initial phase of the ICT, integration and insertion policy has been focused on the bequest connection and operational processes, laying aside educational quality. However, these variables cannot yet be acknowledged due to the lack of rigorous evaluation of the processes and also to the lack of a scrupulous measurement of the social impact.

Therefore, it is imperative to support and consolidate the processes of educational research in ICT pertaining pedagogical models, methodological approaches, assessment and measurement of impact in the sociocultural sphere, among other aspects.

In this interpretation, the analysis model based on the results of the REDCO CIER Occidente project defines the urgency of overcoming the curtailment model, the use and the educational application of ICT as a support tool (educational technology), and to give a step forward to the research stage, both theoretical and application on the usage of ICT as pedagogical conciliations within a curricular integration of these tools. This will overcome educational informatics for access and management of ICT and will define a new stage of critical pondering and analysis of use, reading and production of these new media within didactic and pedagogical conceptions and approaches.

In this new line of work, it is essential to create favorable conditions for the implementation of ICT in the educational processes at all levels of schooling and for this, action plans must be undertaken to consider policies that encourage, sensitize and implement actions in teacher training, availability of content and applications, creation of support networks, and emphasis on research and development.

Another priority in the application and consolidation of ICT is the availability and production of digital content with its corresponding applications. In these aspects, we underscore the Horizon 2020 Report [1] in which the advances made in the ReDco Knowledge Network, the Universidad de Antioquia Subproject of cIER Occidente, are revealed, in response to a need in the local and regional media, which can become a contrivance of these educational innovations, contributing with theoretical and applied construction towards national educational policy of appropriation of ICT.

\section{Problem Definition}

Pertaining to the failures detected in the different stages that have accompanied this implementation, some countries have already become aware that 
data from research is compulsory to improve the processes of exploiting the possibilities offered by ICT to better the quality of education and boost the resources of new modalities and methodological strategies in accordance to the investments made. What there is so far, is based on trial and error exercises, and much more research is still required regarding the pedagogical models and the conditions under which the subjects of the training processes can achieve ICT literacy.

These complete studies of pedagogical models, regarding the educational audience, administer new methods of evaluation in virtual environments and revise the real value in terms of construction and transfer of knowledge in these new educational systems promoted by ICT, where the face-to-face model has been considered an unavoidable condition in educational institutions. In this sense, it is assumed that the new proposals consolidate innovations and the unconventional modalities that advertise the modern ways of producing and transferring knowledge, an area in which universities have already advanced. However, this advance has not been methodologically assessed in its pedagogical strategies, nor in its impact on education.

Currently, developed countries offer incentives for teachers through knowledge networks or collaborative groups, to create their own teaching materials in search of exchange, both domestically and internationally, especially towards Latin American countries for cooperation through socialization of educational content and the offering of pedagogical services. In this sense, it is important to mention the Relpe Red [2] in the Ibero-American context, in which Colombia is an active participant whose main objective is the exchange of educational resources between member countries. This network is set up on the educational level of each country, as a free public service and in accordance with national educational policies. The technological platform is free, and the developed contents are diffusion free.

It is also pointed out that, pertaining the latest diagnoses, the general opinion is that progress has not been as fast as it was sought, and above all, that the outcomes have not been what were expected, the comparative evidence only reports some results in relation to access and frequency of use of ICT. Undoubtedly, the most powerful reason to explain the relative low frequency of use has to do with the current models of education and with the traditional banking model [3] that prevails at all educational levels, where the curriculum of formal education, including Higher Education, with instructive methods leading to degrees, are imposed.

The analysis model presented as a result of the research project in question: "Validation of a methodological matrix for the training of educational agent researchers with the use of ICT through REDCO Knowledge Network as an educational innovation", developed between the years 2014 and 2015 by the Universidad de Antioquia, after the call for bids of the Ministerio de Educación Nacional (MEN)-Colciencias for a pedagogical appropriation of ICT in the innovative schools of CIER Occidente, provides a look at the state and historical moment of the appropriation of educational ICT as a national policy. Although the sample is minor - two educational institutions, compared to ten EI that includes the CIER Occidente-, predict, with the help of the initial diagnoses delivered by the MEN to the five participating universities, and with the theoretical support of the formulation of the research project carried out, the inaccuracies and gaps in the implementation of this field of knowledge, visible in the REDCO CIER Occidente Project, Universidad de Antioquia subcommunity, evidences the need to re-evaluate the methodology and vision for such a policy to have a social impact in the education quality standards of the country.

This moment is considered the appropriate one for the results of the research within CIER Occidente, along with MEN-Colciencias, in their systematization, to define the national approaches for the allotment of the ICT as an educational policy, combining theory, the cross-examination and practice, in a way that promotes leadership in this field, based on innovation observatories, that promotes improvements of educational quality at all levels, taking advantage of ICT as a sustained methodological factor in educational models and institutional guidance.

REDCO Knowledge Network is one of the few cases studied about knowledge networks that are published, according to what was detected in the study. However, it is important to note that, despite these few studies aimed to understand these networks, virtual spaces have increased their number during the last years.

REDCO, then, is interested in exploring these experiences in the academic field, oriented to the contributions that ICT can make to education and 
to knowledge management. It is coordinated by the Education and Virtuality research line [4], attached to the GITT Group, which started participating in 2011 with the creation of REDCO [5]. In REDCO CIER Occidente, the experience is regulated through the analysis model to identify and characterize these knowledge networks and to carry out educational processes at all levels, interdisciplinary and multidisciplinary areas. Their development and dynamics are analyzed from the field of Edu-communication, according to what they have to offer to educational innovation in the knowledge society.

Considering education in the $21^{\text {st }}$ century, implies looking for new options which points to the formation of mindful subjects capable of critically facing the reality that surrounds them in their context. For this reason, REDCo leads to the implementation of new strategies, techniques and educational models that promote the use of information and communication of new technologies as a basis for innovation and as a determinant of development and global competitiveness.

For this purpose, communication becomes a central nerve for educational processes, fostering a potential change in traditional models -in which teaching and learning consisted of a simple accumulation of indeterminate and meaningless information applicable to the social problems and resizing them towards a new educational model that must be horizontal, promoting communication between transmitters-receivers and receivers-transmitters in a communicative and propositive way, according to Cloutier [6]. The results of the analysis model in question are focused on the constant search for those alternatives that favor the new teaching and learning methodologies, where the subjects of the training processes are absorbed in new and innovative strategies provided by the advances of science and technology, which in turn, provide new educational modalities that should contribute to more and better educational opportunities in all social areas, in compliance with the fundamental citizens' rights, as responsibility of Higher Education.

\section{Theoretical Framework}

Due to the rapid evolution of the New Technologies of Information and Communication, society in general has been permeated with great changes in the way they think, perceive and approach the world. Thanks to the evident technological revolution, countless commercial, social, organizational and legal innovations have been made possible, and respond to the characteristics of virtuality and digitality.

As a result, education is part of this permeated, controlled context affected by ICT; concepts such as virtual education or e-learning, multimedia education, multimedia literacy, educational knowledge networks and social networks, among others, are now quite familiar to REDCO CIER Occidente, perhaps because education has been transformed and supplemented to face what many authors insist on calling the "Information Society" and "Knowledge Society" which, while not symmetrical, does share the characteristic of building the "Network society" [7].

It is necessary to think of the new technologies as pedagogical tools that can assist the subjects in the construction of their own knowledge: "To do this, in addition to the subject that 'builds', some 'materials' or information (images, ideas, etc.) are necessary, there are also tools to facilitate the task, a task that starts from the knowledge schemes themselves" [8]. In this sense, it is important to mention that the term technology, in the field of pedagogy, is not necessarily limited to an instrumentalization of the pedagogical process, but that support in the new technologies is connected to guide, support and apply knowledge of other situations [9].

On the other hand, challenges to be faced are of such magnitude that, if they are not addressed with opportunity and diligence, they will expand the differences, inequalities and contradictions that today delay the growth of Latin America and the Caribbean. Antioquia, Colombia is not estranged to this reality. According to the diagnosis made for the elaboration of the Development Plan of the Universidad de Antioquia 2006-2016 [10], "as a product of the historical development model, based on the overexploitation of resources, this natural basis has been subjected to strong processes of degradation and exhaustion". This paper also states that "in the economic growth model implemented, the comparative advantages and productive potential of the sub regions and localities have been wasted to generate their own territorial development".

In this respect, the university plays an important role in the process of regional development since its interventions must guide the recognition of these advantages and potentialities, as well as 
enable the articulation of different social, governmental and institutional organizations to identify the various factors of regional development and adopt a way that satisfies the general needs, agglutinating the challenges that the model represents. It is in this perspective that scholars and researchers must combine efforts for the construction and transfer of knowledge in educational processes, so through the application and inference of inter- and multidisciplinary knowledge, they can transform the realities of communities of today's society. This includes a change in the role of educational institutions, against considerations to maintain the status quo.

Within the possibilities offered by the academic networks, REDCO is inserted in this new dynamic, opening to the possibility for undertaking projects with the concurrence of multiple institutions, either public or private, taking advantage of distributed resources and cooperative work supported by the new technologies, striking and boosting the effort of the country's academic community. Systematization of knowledge has become a daily practice; however, a great gap remains in the lack of a real and effective digital literacy, especially in the processes of coaching at all educational levels.

A key challenge is not only to think of the use of emerging technologies per se, but to place them within the dialectic of information processing for solving the convoluted problems of society and one of the major challenges of Higher Education. The problem cannot be reduced to the implementation of new technologies, but of specific educational processes in which analysis, inference and understanding of what these new technologies imply and in culture, stimulating critical thinking and creativity towards the empowerment of the transformation of social actors and their communities.

An adaptation of the teaching practices to accommodate to the requirements of the digital environment and of knowledge is necessary. Horizon 2020 technologies, are collaborative environments and social media. In this sense, the REDCO model of analysis as knowledge network poses and characterizes the development of training processes carried out in two of the educational EI of CIER Occidente. Some of the distinctiveness of both institutions as subjects of the ICT-based training processes are implemented within REDCO in the development of the project. In this way, it recommends the creation of networks such as nodes and knowledge alliances among different actors, environments and educational scenarios to develop cooperative work that may lead to the compliance of educational quality assurance in the perspective of the laws of science and technology, where innovation becomes the guarantor of the country's competitiveness and global productivity.

REDCO, with the Edu-communication component, has undertaken the educational task through a knowledge network, as a communication continuum that ensures socialization of academic and sociocultural groups towards the creation of collaborative work, focusing on the proposal of knowl-edge networks as educational scenarios, where subjects are formed and transformed through interaction. Therefore, REDCO is considered a valuable knowledge network. As it develops, it has been made evident that from this experience the subjects assume relevant roles to manage knowledge helpfully. If this transformation continues, Freire's words become crucial [11]: "True education is praxis, reflection and action of man on the world to transform it". In this sight, we recognize that, in the spheres of educational projects which allow the construction of knowledge and the formation of critical subjects capable of evolving in their environment as social and political subjects. A contribution is made to improve the welfare of the population, which is important to fulfill fundamental rights of human beings.

Authors such as M. Albornoz and C. Alfaraz [12] agree that "networking is the result of the adoption of flexible and participatory forms of organization, implemented in creating and applying knowledge to problem solving. In fact, networks of knowledge are the configurations in which many of the characteristics mentioned are conjugated: in them, actors from different backgrounds are related in order to address concrete problems and propose solutions, putting their skills at stake and, by this means, to complement them".

Given this scenario, the Education and Virtuality research line has presented this model of analysis in accordance with the purpose of the REDCO CIER Occidente project which, evidences its aim to contribute and continue working in the ICT educational policy in the country, which considers essential, and, moreover, how actions, processes and programs should really be oriented towards the consolidation of CIER in Colombia.

In agreement with the above one may establish the following tasks as mandatory: to incorporate 
research with its results, control how actions and processes can be developed, monitor what has been done so far and what is still pending, gauging the social impact. In the same way, in their search for the formation of communities, research should be a core to building synergies, to unite and integrate groups, creating new networks based on those policies that go together with the global scenario of the 21 st century society. In addition, applied research will enable decision making, from an operational level to the highest academic level in this area of knowledge that would lead to problem solving within the national and/or regional context.

\section{Conclusions}

Considering that virtuality is the main scenario in REDCO, in its structure and functioning, it is possible to recognize difficulties and achievements that are attributable to virtual scenarios and that, far from hampering its purposes, present possibilities of constant reflection allowing to assume attitudes of change towards the new realities of the 21st century. As a virtual scenario, the REDCo Knowledge Network is not estranged to the difficulties that arise from the technological infrastructure in such substantial aspects as connectivity, operability, and navigability. Nowadays the methodological / pedagogical component, the training of teachers in ICT is substantial to guarantee the competencies necessary for the Information and Knowledge Society. These competencies are reflected in the REDCO CIER Occidente project in the interdisciplinary field of Edu-communication, which includes: the intervention of communication as a substantial nerve of educational processes, either as an expression or as a model of dialogic and horizontal communication that intervenes in the Multimedia Literacy (Treatment of media as objects of study, didactic means and educational resources, including digital media), Multimedia Education and ICT curriculum integration, Pedagogical Mediation, Virtual Learning Scenarios, Knowledge Management and Transfer (GC).

The technological platforms that support REDCO offer multiple possibilities for interaction and communication, to facilitate teaching and learning processes from active participation and collaborative work, since the methodology that guides the processes, allows the generation of dynamics, constant participation and dialogical communication. However, the subjects, their configurations and their interests also play a determining role in ensuring the use of these scenarios: this contributes to technological infrastructure factors and methodological aspects related to the subjects' educational or sociocultural actions involved in the processes.

REDCO CIER Occidente promotes teacher training, considering that the value chain in the education sector starts with the teachers, who program the learning activities of students, who need to improve the processes, use new media and share knowledge and good practices that may improve the educational service and its results. Also, they are expected to be multipliers and have social impact -in the organization's social capital- that may influence the professional profiles-competences for world labor and in all areas of knowledge for the country's sustainable development. Equally, it is urgent to teach at all educational levels adopting the new method of communicating knowledge, the use and appropriation of technology as a factor of change and social innovation, the entrepreneurship, competitiveness and productivity applied to reach the labor profiles required by the country.

Therefore, the project in question originates with the compelling need to be competitive in the "Global Village" [13], hence the concept of scientific-technical multired, defined as the so-called social capital adapted to a scientific structure and sense of duty. There is nothing more important for socio-economic growth, social equity, and the deepening of democracy, than to make quality education more accessible, widespread and equitable, to have social science development (E-science), technology and innovation, to detect the potentials of each community and generate collective projects.

\section{References}

[1] European Commission, "Horizon 2020 Report. First results", Directorate-General for Research and Innovation, Brussels, Belgium, 2015. Available: https:// ec.europa.eu/programmes/horizon2020/sites/horizon2020/files/horizon_2020_first_results.pdf

[2] Red Latinoamericana portales educativos (RELPE). Available: http://www.relpe.org/ 
[3] P. Freire, The political nature of education, Ministry of Education and Science. Barcelona, Spain: Editions Paidos Ibérica. 1990.

[4] Research Line Education and Virtuality. Available: http://linea.comunidadredco.com/ (in re-design).

[5] REDco Knowledge Network. Available: http://comunidadredco.com/ (in re-design).

[6] J. Cloutier, L'ere d'Emerec, Montreal, Canada: University of Montreal, 1975.

[7] M. Castel. The Red Society, Spain: Edit. Alia, 2006.

[8] A. Gutiérrez. Multimedia Education and New Technologies. Madrid, Spain: De La Torre editions, 1991.

[9] E. Ramírez. Conceptual and methodological strategies for the construction of today's knowledge, Medellín: Zuluaga, 2003.

[10] Universidad de Antioquia, Plan de desarrollo 2006-2016. Una universidad investigadora, innovadora y humanista al servicio de las regiones y del país, Medellín, Colombia: Oficina de Planeación, Universidad de Antioquia, Nov. 2006. Available: http://www.udea.edu.co/wps/wcm/connect/udea/ 215c33a8-3909-484c-9b84-c94a8459dc83/plan-dllo-2006-2016.pdf?MOD=AJPERES

[11] P. Freire, Liberating Education, Medellín: Prisma, 1972.

[12] M. Albornoz \& C. Alfaraz. Redes de conocimiento: construcción, dinámica y gestión. Buenos Aires, Argentina: Ibero-American Network of Science and Technology Indicators (RICYT) and UNESCO Regional Office for Science in Latin America and the Caribbean, 2006. Available: http://www.ricyt. org/manuales/doc_view/26-redes-de-conocimiento-construccion-dinamica-y-gestion

[13] M. Mcluhan. La Aldea Global,The Gutenberg Galaxy: The Making of Typographic Man (1962) y Understanding Media (1964). 